\title{
Fluoxetine Inhibits DNA Repair and NF-kB-modulated Metastatic Potential in Non-small Cell Lung Cancer
}

\author{
JENG-YUAN WU ${ }^{1,2}$, SONG-SHEI LIN ${ }^{3 *}$, FEI-TING HSU ${ }^{4 *}$ and JING-GUNG CHUNG ${ }^{4,5 *}$ \\ ${ }^{1}$ Department of Thoracic Surgery, Taichung Tzu Chi Hospital, \\ Buddhist Tzu Chi Medical Foundation, Taichung, Taiwan, R.O.C.; \\ ${ }^{2}$ School of Medicine, Tzu Chi University, Hualien, Taiwan, R.O.C.; \\ ${ }^{3}$ Department of Medical Imaging and Radiological Sciences, \\ Central Taiwan University of Science and Technology, Taichung, Taiwan, R.O.C.; \\ ${ }^{4}$ Department of Biological Science and Technology, China Medical University, Taichung, Taiwan, R.O.C.; \\ ${ }^{5}$ Department of Biotechnology, Asia University, Taichung, Taiwan, R.O.C.
}

\begin{abstract}
Background/Aim: The aim of present study was to verify the effect of fluoxetine on DNA repair and metastatic potential in non-small cell lung cancer (NSCLC) in vitro. Materials and Methods: Highly metastatic NSCLC CL1-5-F4 cells were used in this study. Cells were treated with different concentrations of fluoxetine or $Q N Z$ ( $N F-k B$ inhibitor) for $48 \mathrm{~h}$. After treatment, cell viability, apoptotic signaling, $N F-k B$ activation, expression of DNA repair and metastasis-associated proteins, and cell migration/invasion were evaluated by $(4,5$ dimethylthiazol-2-yl)-2,5-diphenyltetrazolium assay, flow cytometry, $N F-k B$ reporter gene, western blotting, and cell migration/invasion assay, respectively. Results: Fluoxetine induced apoptosis and reduced cell viability, $N F-k B$ activation, expression of DNA repair and metastasis-associated proteins, and cell migration/invasion in CL1-5-F4 cells. Also, $N F-k B$ activation was the critical factor in fluoxetine-inhibited metastatic potential. Conclusion: Fluoxetine induced apoptosis and inhibited DNA repair and metastatic potential in NSCLC CL1-5-F4 cells.
\end{abstract}

Lung cancer is divided into two categories, small cell lung cancer (SCLC) and non-small cell lung cancer (NSCLC), and is the leading cause of cancer-related death worldwide (1). NSCLC accounts for $85 \%$ of all lung cancers and includes adenocarcinoma (AC), squamous cell carcinoma (SCC), and

*These Authors contributed equally to this study.

Correspondence to: Professor Jing-Gung Chung, Department of Biological Science and Technology, China Medical University, No 91, Hsueh-Shih Road, Taichung, Taiwan, R.O.C. Tel: +886 422053366, ext. 8000, Fax: +886 422053764, e-mail: jgchung@mail.cmu.edu.tw

Key Words: Non-small cell lung cancer, fluoxetine, NF-кB, DNA repair, metastatic potential. large cell carcinoma (LCC) (2). Chemotherapeutic agents that induce DNA damage and lead to cell apoptosis are used to treat lung cancer (3). Chemotherapeutic agent-induced DNA damage can be repaired by efficient DNA repair capacity (DRC) resulting in treatment failure. Effective DRC contributes to poor prognosis in NSCLC patients treated with chemotherapy, but is not associated with survival of patients who do not receive chemotherapy (4). Tumor metastasis is a major cause of death in patients with lung cancer (5). Furthermore, patients with metastatic NSCLC often have unsatisfactory response to chemotherapy, radiotherapy, or chemoradiotherapy and their median survival is less than 32 months (6). Therefore, development of new adjuvants which inhibit DNA repair and tumor metastasis may provide benefits for patients with NSCLC.

Antidepressants have a long history in the treatment of mood disorders. In addition, some studies indicated that antidepressants have anti-cancer potential in various cancers (7). Zingone et al., found that lung cancer patients treated with antidepressants [dopamine reuptake inhibitors (NDRIs) or tricyclic antidepressants (TCA)] have a significantly better survival as compared to patients not treated with antidepressants (8). Imipramine, a tricyclic antidepressant, induces cell death by enhancing activation of stress pathways in a SCLC model in vitro and in vivo (9). Antidepressants may be used as potential adjuvants for lung cancer treatment. Fluoxetine, an antidepressant, belongs to selective serotonin reuptake inhibitors (SSRIs) which are widely used to treat depression and anxiety disorders. In addition, many studies have indicated that fluoxetine has anti-inflammatory and anticancer effects $(10,11)$. Fluoxetine ameliorates dextran sulfate sodium (DSS)-induced colitis through inhibition of NF-kB signaling in mice (12). Helga et al. suggested that fluoxetine inhibited development of colon tumor via disruption of tumor metabolism (10). However, whether fluoxetine inhibits DNA repair and metastasis in NSCLC is ambiguous. Therefore, the 
A

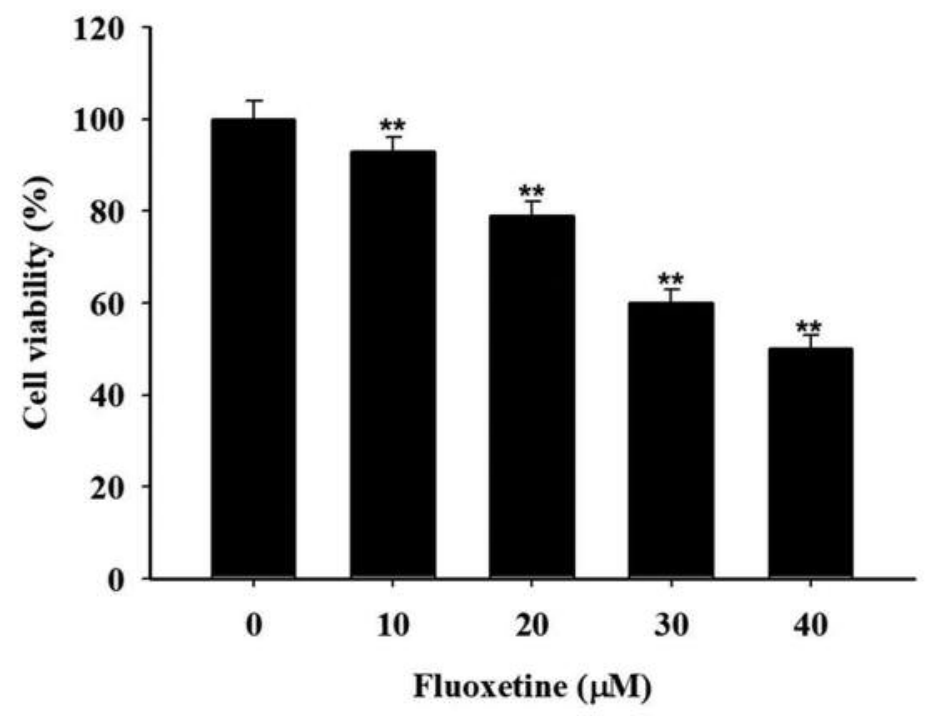

B

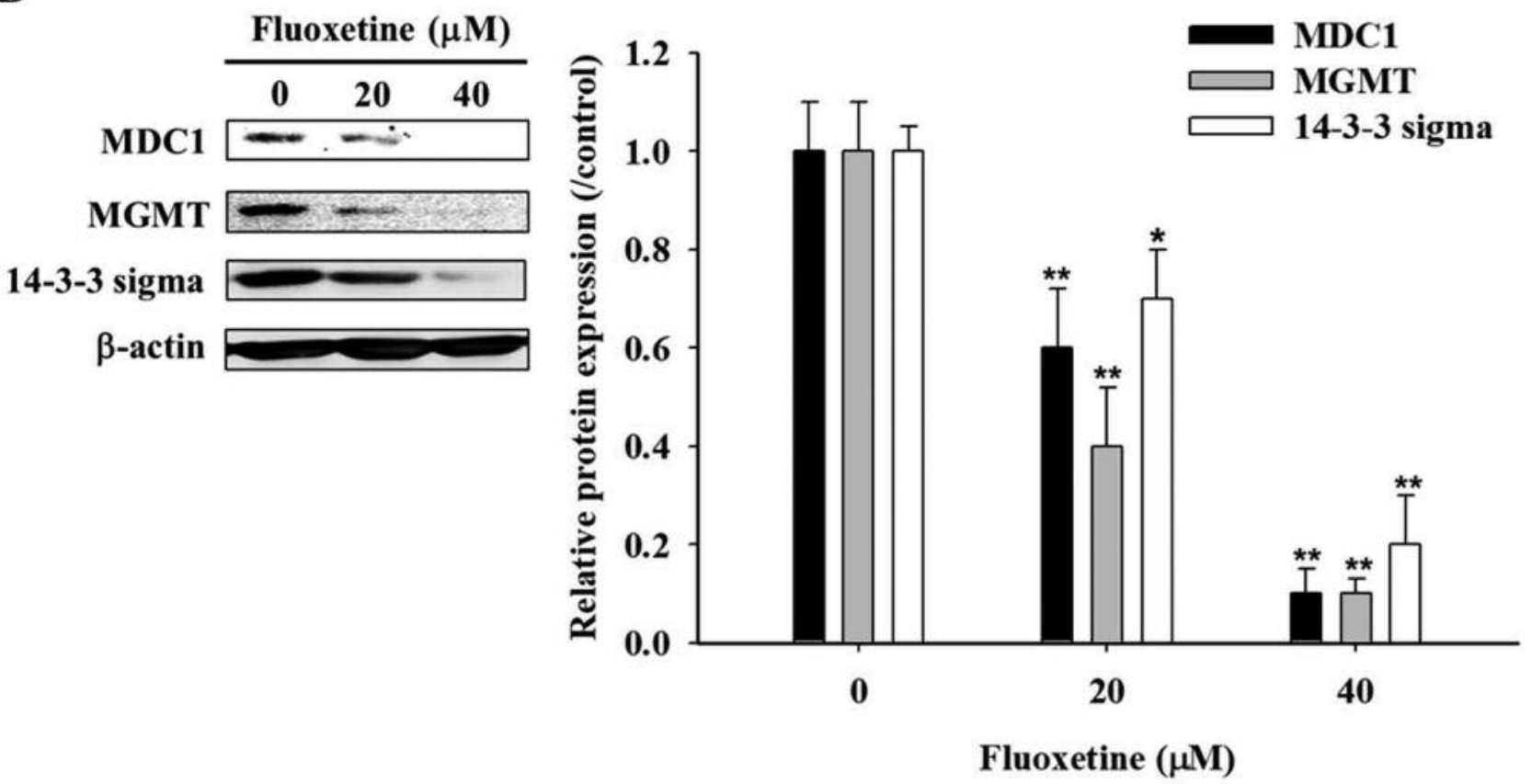

Figure 1. Continued

effect of fluoxetine on DNA repair and metastatic potential in NSCLC CL1-5-F4 cells was investigated.

\section{Materials and Methods}

Chemicals. Fluoxetine and 3-(4, 5-Dimethylthiazol-2-yl)-2,5diphenyltetrazolium bromide (MTT) were purchased from SigmaAldrich (St. Louis, MO, USA). Dulbecco's modified Eagle's medium (DMEM), fetal bovine serum (FBS), L-glutamine and penicillin- streptomycin (PS) were obtained from Gibco/Life Technologies (Carlsbad, CA, USA). NF-kB inhibitor 4-N-[2-(4-phenoxyphenyl) ethyl] quinazoline-4, 6-diamine (QNZ or EVP4593) were bought from Selleckchem (Houston, TX, USA). JetPEI ${ }^{\mathrm{TM}}$ transfection reagent was bought from Polyplus Transfection (Sélestat, Bas-Rhin, France). D-luciferin was purchased from Promega (Madison, WI, USA). Hygromycin was obtained from Santa Cruz Biotechnology (Santa Cruz, CA, USA). Matrigel was obtained from Corning (Tewksbury, MA, USA). Primary antibodies against VEGF and MMP-9 were purchased from Merck Millipore (Billerica, MA, 
C

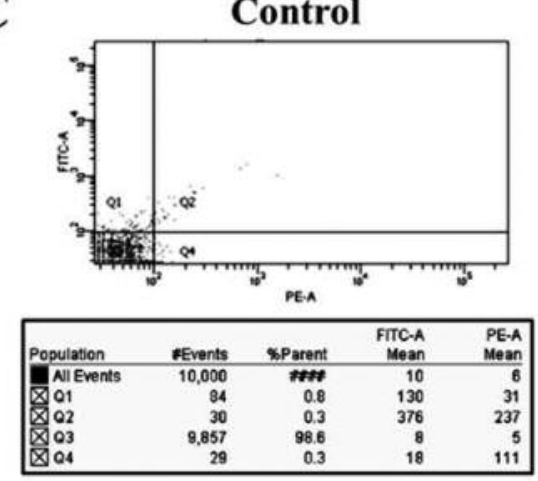

Fluoxetine $(20 \mu \mathrm{M})$

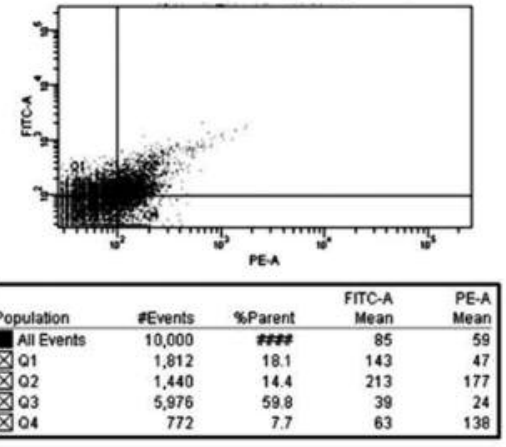

Fluoxetine $(40 \mu \mathrm{M})$

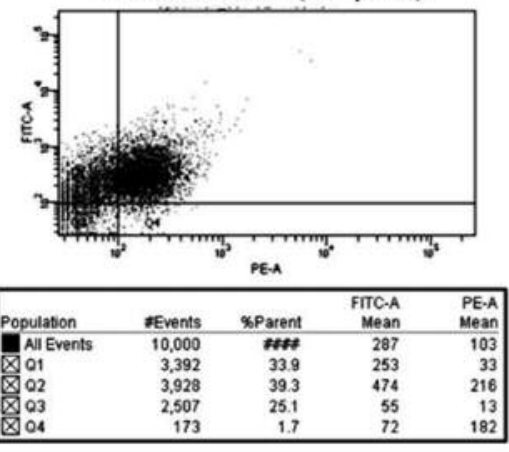

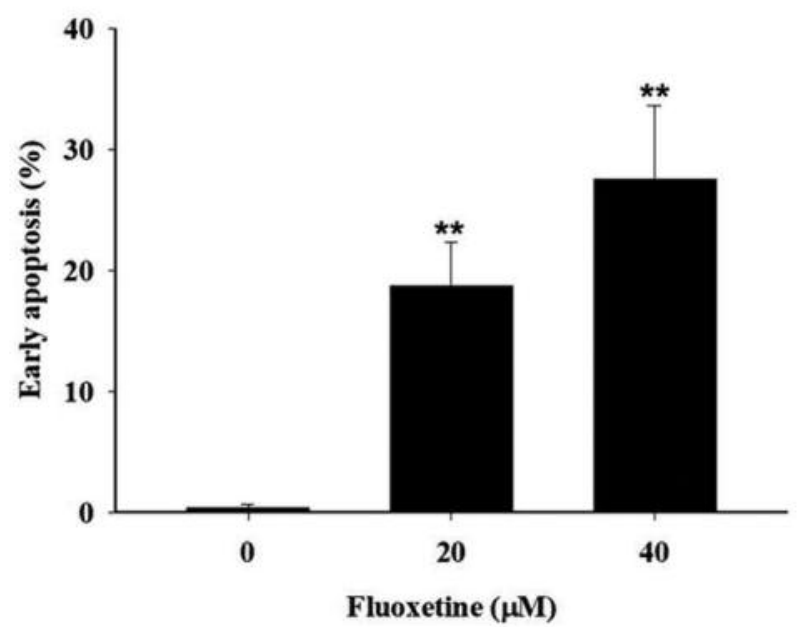

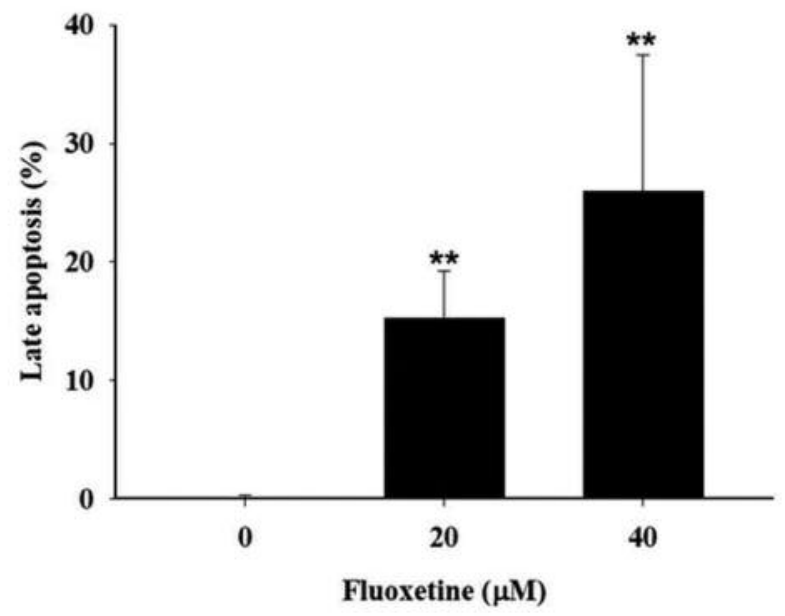

Figure 1. Effect of fluoxetine on cell growth and expression of DNA repair-associated proteins in CL1-5-F4 cells. Cells were treated with different concentrations of fluoxetine for $48 \mathrm{~h}$. (A) Cell viability was evaluated using the MTT assay. (B) Protein levels of MDC1, MGMT, and 14-3-3 sigma were determined by western blotting. (C) Detection of apoptosis was performed by using flow cytometry. $* p<0.05$ as compared to $0 \mu M$ fluoxetine.

USA). Primary antibodies against MMP-2 and uPA were obtained from OriGene Technologies (Rockville, MD, USA) and Abbiotec (San Diego, CA, USA), respectively. Primary antibodies against MDC1, MGMT, and 14-3-3 sigma were purchased from Biorbyt (South San Francisco, CA, USA), Thermo Fisher Scientific (Waltham, MA USA), and GeneTex (Irvine, CA, USA), respectively. Primary antibody against $\beta$-actin was obtained from Santa Cruz Biotechnology (Santa Cruz, CA, USA). Secondary antibodies were bought from Jackson ImmunoResearch (West Grove, PA, USA). Annexin V-Fluorescein isothiocyanate (FITC) apoptosis detection kit was bought from BioVision (Milpitas, CA, USA).

Cell culture. Human lung adenocarcinoma cell line CL1-5-F4 was obtained from Dr. Chia-Lin Hsieh (Taipei Medical University, Taiwan) and used for this study. Cells were grown in Dulbecco's Modified Eagle's Medium (DMEM) and Ham's F-12 Nutrient Mixture supplemented with $10 \%$ FBS, $2 \mathrm{mM}$ L-glutamine, 100 $\mathrm{U} / \mathrm{ml}$ penicillin, and $100 \mathrm{mg} / \mathrm{ml}$ streptomycin. Cells were incubated at $37^{\circ} \mathrm{C}$ in a humidified incubator containing $5 \% \mathrm{CO}_{2}$ and $95 \%$ air (13).
3-(4,5-Dimethylthiazol-2-yl)-2,5-diphenyltetrazolium bromide (MTT) assay. CL1-5-F4 cells were seeded into 96-well plates with a density of $2 \times 10^{4}$ cells/well and incubated overnight. Cells were treated with different concentrations of fluoxetine $(0-40 \mu \mathrm{M}$ in $0.1 \%$ DMSO) or QNZ (0-1 $\mu \mathrm{M}$ in $0.1 \%$ DMSO) for $48 \mathrm{~h}$. Cell viability of CL1-5-F4 was then evaluated by MTT assay as described by Liu et al. (14).

Detection of apoptosis. CL1-5-F4 cells were seeded into 12-well plates with a density of $2 \times 10^{5}$ cells/well and incubated overnight. Cells were treated with different concentrations of fluoxetine $(0,20$, and $40 \mu \mathrm{M}$ in $0.1 \%$ DMSO) for $48 \mathrm{~h}$. After treatment, cells were harvested and washed twice by centrifugation and phosphatebuffered saline (PBS) and then re-suspended in $500 \mu \mathrm{l}$ PBS. Cell suspension was stained with $5 \mu \mathrm{l}$ of annexin-V-FITC and propidium iodide [(PI) $50 \mathrm{mg} / \mathrm{ml}]$ for $5 \mathrm{~min}$ in the dark. Distri-bution of annexin-V and PI was evaluated by using flow cytometry with FL1 and FL2 channels.

Western blotting assay. $3 \times 10^{6} \mathrm{CL} 1-5-\mathrm{F} 4$ cells were seeded into $10 \mathrm{~cm}$ diameter dishes and incubated overnight. Cells were treated with 0 , 
A
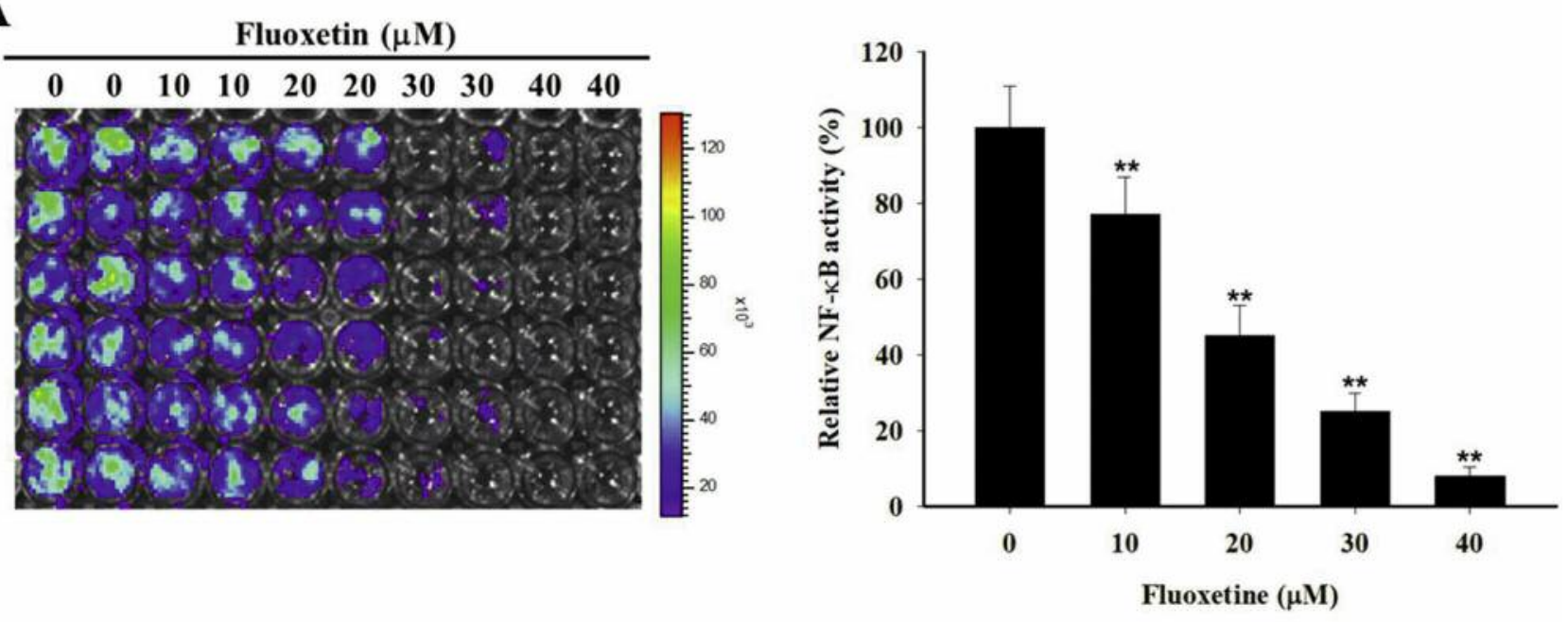

B
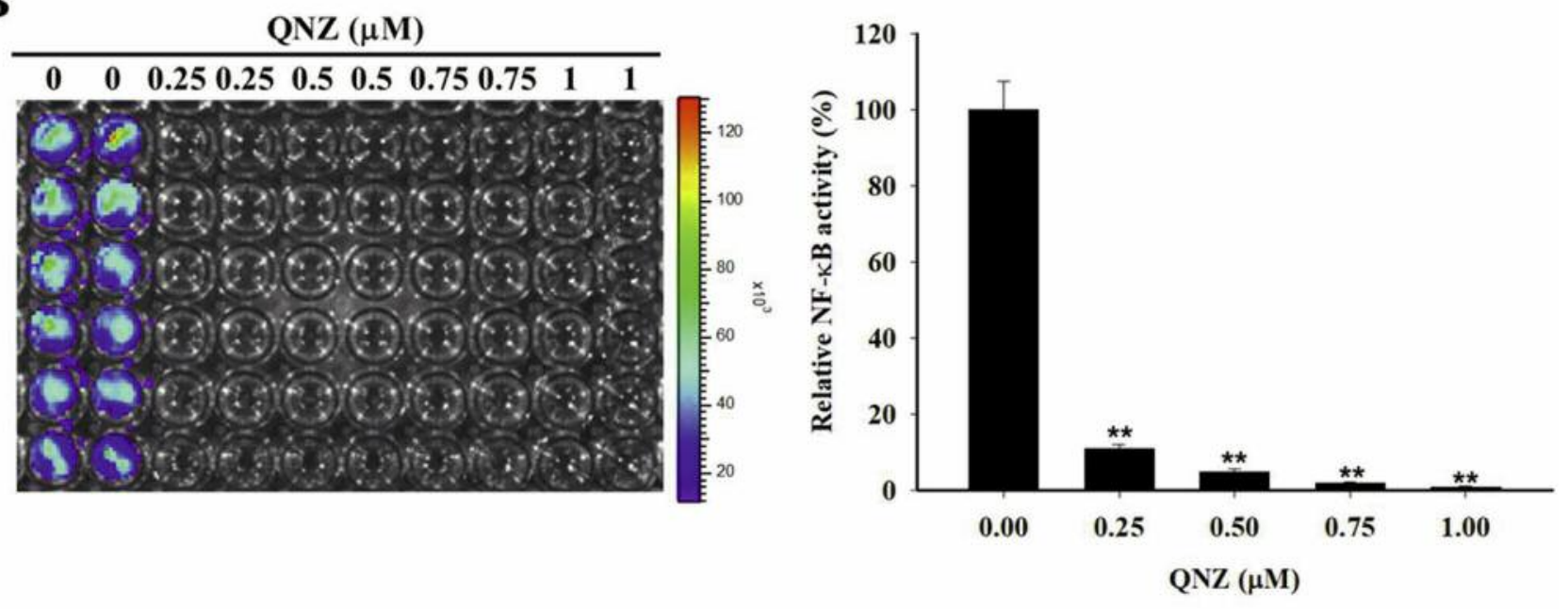

Figure 2. Effect of both fluoxetine and QNZ (NF-kB inhibitor) on NF-kB activation in CL1-5-F4 cells. Cells were treated with different concentrations of (A) fluoxetine or (B) QNZ for $48 \mathrm{~h}$. NF-kB activation was investigated using an NF-kB reporter gene assay. ** $<0.01$ as compared to $0 \mu M M$ fluoxetine.

20, $40 \mu \mathrm{M}$ fluoxetine or $0.25 \mu \mathrm{M}$ QNZ for $48 \mathrm{~h}$. Cell lysis buffer $(50 \mathrm{mM}$ Tris- $\mathrm{HCl} \mathrm{pH} 8.0,120 \mathrm{mM} \mathrm{NaCl}, 0.5 \% \mathrm{NP}-40$, and $1 \mathrm{mM}$ phenylmethanesulfonyl fluoride) was used to extract total proteins from cells. Expression of MDSC1, MGMT, 14-3-3 sigma, VEGF, MMP-2, MMP-9, and uPA proteins was investigated by using western blotting assay as described by Wang et al. (15). Protein expression was finally visualized by ChemiDoc MP Imaging System (Bio-Rad Laboratories Inc., Hercules, CA, USA). The intensity of protein bands was quantified using Image Lab (Bio-Rad Laboratories Inc.).

Plasmid transfection. NF-kB-luciferrase2 vector (pNF-kB/luc2) was bought from Promega (Madison, WI, USA). One million CL1-5-F4 cells were seeded into $10 \mathrm{~cm}$ diameter dishes and incubated overnight. Cells were transfected with $\mathrm{pNF}-\mathrm{kB} / \mathrm{luc} 2$ by using jetPEI (Polyplus transfection, New York, NY, USA) transfection reagent as previously described (16).
$N F-k B$ reporter gene assay. CL1-5-F4 cells transfected with pNF$\mathrm{KB} /$ luc2 were seeded into 96 -well plates with a density of $2 \times 10^{4}$ cells/well and incubated overnight. Cells were treated with different concentrations of fluoxetine $(0-50 \mu \mathrm{M}$ in $0.1 \%$ DMSO) or QNZ $(0-$ $1 \mu \mathrm{M}$ in $0.1 \%$ DMSO) for $48 \mathrm{~h}$. After treatments, $100 \mu \mathrm{l}$ of $15 \mathrm{D}-$ luciferin solution (500 $\mu \mathrm{M}$ D-luciferin in $100 \mu \mathrm{l}$ PBS) were added into each well and incubated for $1 \mathrm{~min}$. Photon emission from cells was acquired for $1 \mathrm{~min}$ by IVIS100 Imaging System (Xenogen, Alameda, CA, USA) and photons per second were quantified by using Living Image software (Xenogen). Relative NF-kB activity was corrected with cell viability as previously described (17).

Cell migration assay. Transwell inserts of $8 \mu \mathrm{m}$ pore size were obtained from Corning (Tewksbury, MA, USA). 3×106 CL1-5-F4 cells were seeded into $10 \mathrm{~cm}$ diameter dishes and incubated overnight. Cells were treated with $40 \mu \mathrm{M}$ fluoxetine or $0.25 \mu \mathrm{M}$ 

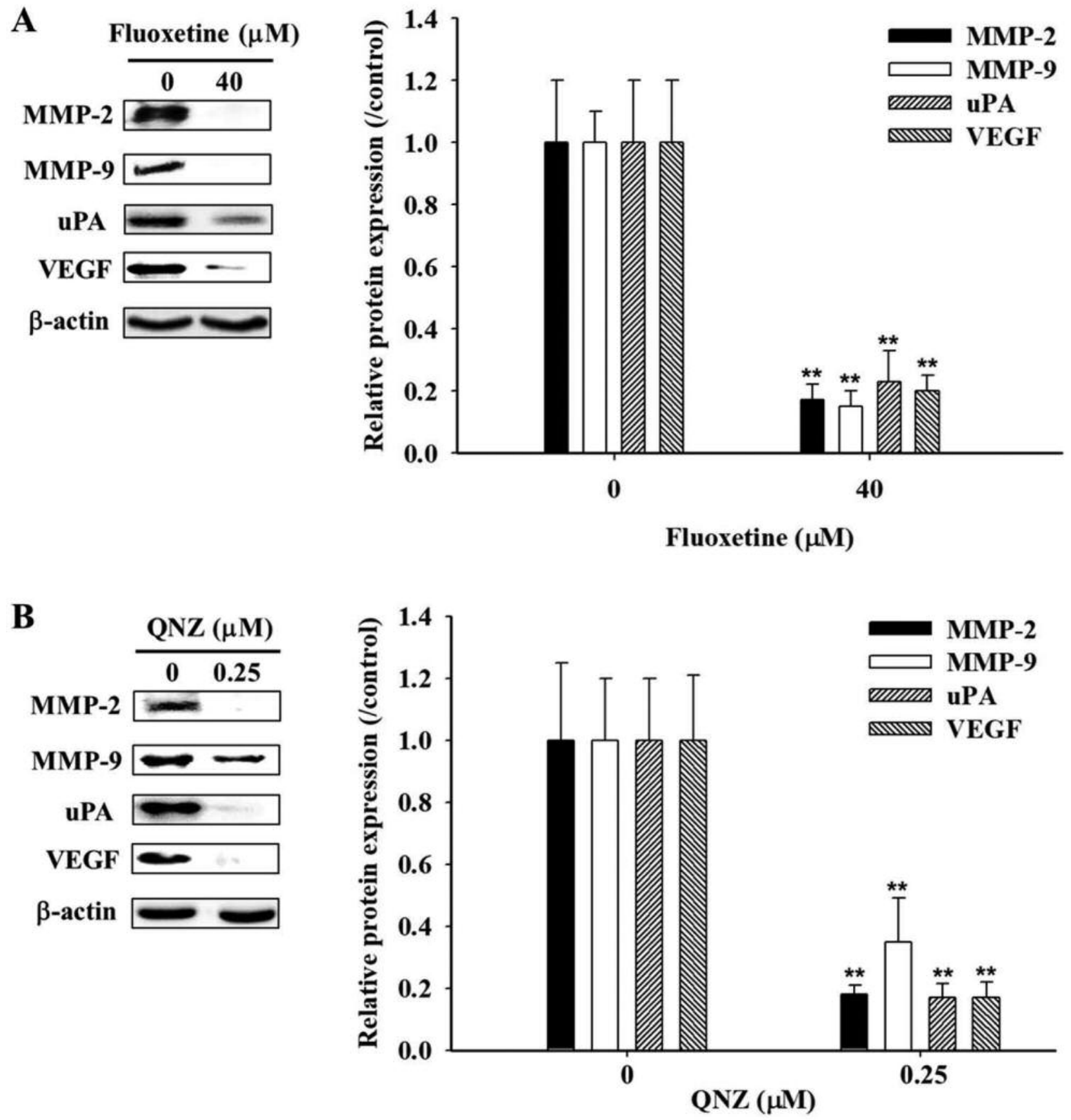

Figure 3. Effect of both fluoxetine and QNZ (NF-kB inhibitor) on the expression of metastasis associated proteins in CL1-5-F4 cells. Cells were treated with (A) $40 \mu M$ fluoxetine or (B) $0.25 \mu M Q N Z$ for 48 h. Protein levels of MMP-2, MMP-9, uPA, and VEGF were evaluated by western blotting. ${ }^{* * p}<0.01$ as compared to $0 \mu M$ fluoxetine or $Q N Z$.

QNZ for $48 \mathrm{~h}$. After treatment, cell viability was rapidly determined with trypan blue, and then migration ability of $1 \times 10^{6}$ viable cells was investigated as previously described (18). Migrated cells in were photographed under a light microscope at $100 \times$ and cell number was quantified with the ImageJ software (National Institutes of Health, Bethesda, MD, USA).
Cell invasion assay. Fifty microliter matrigel solution $(25 \mu \mathrm{l}$ matrigel in $25 \mu \mathrm{l}$ serum-free medium) was added to transwell inserts of $8 \mu \mathrm{m}$ pore size and incubated overnight. Three million CL1-5$\mathrm{F} 4$ cells were seeded into $10 \mathrm{~cm}$ diameter dishes and incubated overnight. Cells were treated with $40 \mu \mathrm{M}$ fluoxetine or $0.25 \mu \mathrm{M}$ QNZ for $48 \mathrm{~h}$. After treatment, cell viability was rapidly determined 
with trypan blue, and then invasion ability of $1 \times 10^{6}$ viable cells was investigated as described by Pan et al. (19). Invaded cells were photographed under a light microscope at $100 \times$ and the number of invaded cells was quantified with ImageJ software (National Institutes of Health).

Statistical analysis. Parametric data were presented as the mean \pm standard deviation. Student $t$-test was used to determine the significance of means difference between two groups. $p$-Value less than 0.05 was defined as statistically significant. Excel 2017 (Microsoft, Redmond, WA, USA) was used for statistical analyses in this study.

\section{Results}

Fluoxetine diminished cell viability, expression of DNA repairassociated proteins and induced apoptosis in CL1-5-F4 cells. Effect of fluoxetine on cell growth and expression of DNA repair-associated proteins was evaluated by MTT assay, flow cytometry, and western blotting assay. Figure 1A indicates that fluoxetine significantly reduced cell viability of CL1-5-F4 cells by $7 \%-53 \%$ as compared to control (vehicle treatment). After $48 \mathrm{~h}$ treatment, the half maximal inhibitory concentration $\left(\mathrm{IC}_{50}\right)$ of fluoxetine was about $40 \mu \mathrm{M}$. Fluoxetine significantly inhibited expression of DNA repairassociated proteins [mediator of DNA damage checkpoint 1 (MDC1), $\mathrm{O}^{6}$-methylguanineDNA methyltransferase (MGMT), and 14-3-3 sigma] by 30-90\% as compared to control (Figure 1B). Additionally, fluoxetine significantly induced apoptosis by $18-27 \%$ as compared to control (Figure 1C).

Both fluoxetine and $Q N Z(N F-k B$ inhibitor) suppressed $N F$ $\kappa B$ activation of CL1-5-F4 cells. NF- $\mathrm{KB}$ activation is required for tumor metastasis (14). After treatment with fluoxetine or QNZ for $48 \mathrm{~h}, \mathrm{NF}-\mathrm{kB}$ activation was evaluated using an NF reporter gene assay. Fluoxetine significantly inhibited NF-kB activation of CL1-5-F4 cells by $23 \%-96 \%$ at $48 \mathrm{~h}$ as compared to control (Figure 2A). In addition, NF-kB activation was also inhibited by $(0.25-1.0 \mu \mathrm{M})$ QNZ treatment for $48 \mathrm{~h}$ (Figure 2B).

Both fluoxetine and QNZ (NF-kB inhibitor) inhibited expression of metastasis-associated proteins in CL1-5-F4 cells. Effect of both fluoxetine and QNZ on expression of metastasis-associated proteins was determined by western blotting assay. The protein levels of MMP-2, -9, uPA, and VEGF were significantly decreased after treatment with $40 \mu \mathrm{M}$ fluoxetine or $0.25 \mu \mathrm{M}$ QNZ for $48 \mathrm{~h}$ by $70-90 \%$ and $65-82 \%$ respectively, as compared to control (Figure $3 \mathrm{~A}$ and $\mathrm{B}$ ).

Both fluoxetine and QNZ (NF-kB inhibitor) reduced cell migration and invasion in CL1-5-F4 cells. Cell migration and invasion assay was used to investigate whether fluoxetine and QNZ can inhibit migration and invasion of CL1-5-F4 cells. Forty $\mu \mathrm{M}$ fluoxetine significantly inhibited the number of migrated and invaded cells as compared to control (Figure 4A and B). QNZ significantly reduced cell migration and invasion as compared to control (Figure 4C and D).

\section{Discussion}

Acquired resistance to chemotherapeutic agents in NSCLC can be mediated by DNA repair mechanisms. Aberrant expression of DNA repair-associated proteins correlates with poor prognosis in patients with NSCLC (3-4). 14-3-3 sigma protein enhances non-homologous end joining (NHEJ) repair of radiation-induced DNA double strand breaks leading to inhibition of radiation-induced $\mathrm{G}_{2} / \mathrm{M}$ phase arrest and apoptosis (20). Cetintas et al., found that increased expression of 14-3-3 sigma diminished cisplatin efficacy in NSCLC in vivo (21). $\mathrm{O}^{6}$-methylguanine-DNA methyltransferase (MGMT), a DNA repair protein, reduced alkylating agentsinduced cytotoxicity by removing alkyl adducts from the $\mathrm{O}^{6}$ position of guanine in DNA (22). Brabender et al., indicated that MGMT expression is associated with chemotherapy response and outcome in patients with NSCLC (23). Mediator of DNA damage checkpoint protein 1 (MDC1), a protein involved in DNA strand break repair, regulates cell resistance to chemotherapy and radiotherapy in breast and nasopharyngeal cancer (24-25). Fluoxetine has been shown to induce cell death in NSCLC A549 cells (26). However, whether fluoxetine inhibits DNA repair potential was not exam-ined. The results presented here showed that fluoxetine induced apoptosis and inhibited expression of DNA repairassociated proteins MDC-1, MGMT, and 14-3-3 sigma in NSCLC CL1-5-F4 cells.

Many breast or lung cancer patients have symptomatic brain metastases $(27,28)$. Shapovalov et al. showed that fluoxetine promotes breast cancer metastasis to brain in a murine model. They suggested that increased numbers of brain metastases by fluoxetine were accompanied by enhanced permeability of the blood-brain barrier, changes of pro-inflammatory cytokines in the brain, and glial activation (27). CL1-5-F4, a highly metastatic lung adenocarcinoma cell line, was derived from lung metastases of severe combined immunodeficient mice inoculated with CL1-5 cells (29). In this study, this highly metastatic cell line was used to verify the anti-metastatic effect of fluoxetine. Contrary to its effect in breast cancer, fluoxetine significantly reduced migration and invasion abilities of NSCLC CL1-5-F4 cells (Figure 4A and B). Expression of metastasis-associated proteins MMP-2, -9, uPA, and VEGF contributes to tumor metastasis. High expression of metastasis-associated proteins was observed in patients with metastatic NSCLC (6-9). Moreover, protein levels of MMP-2, -9, uPA, and VEGF were significantly diminished by $40 \mu \mathrm{M}$ fluoxetine treatment for $48 \mathrm{~h}$ in CL1-5-F4 cells (Figure 3A). 
A
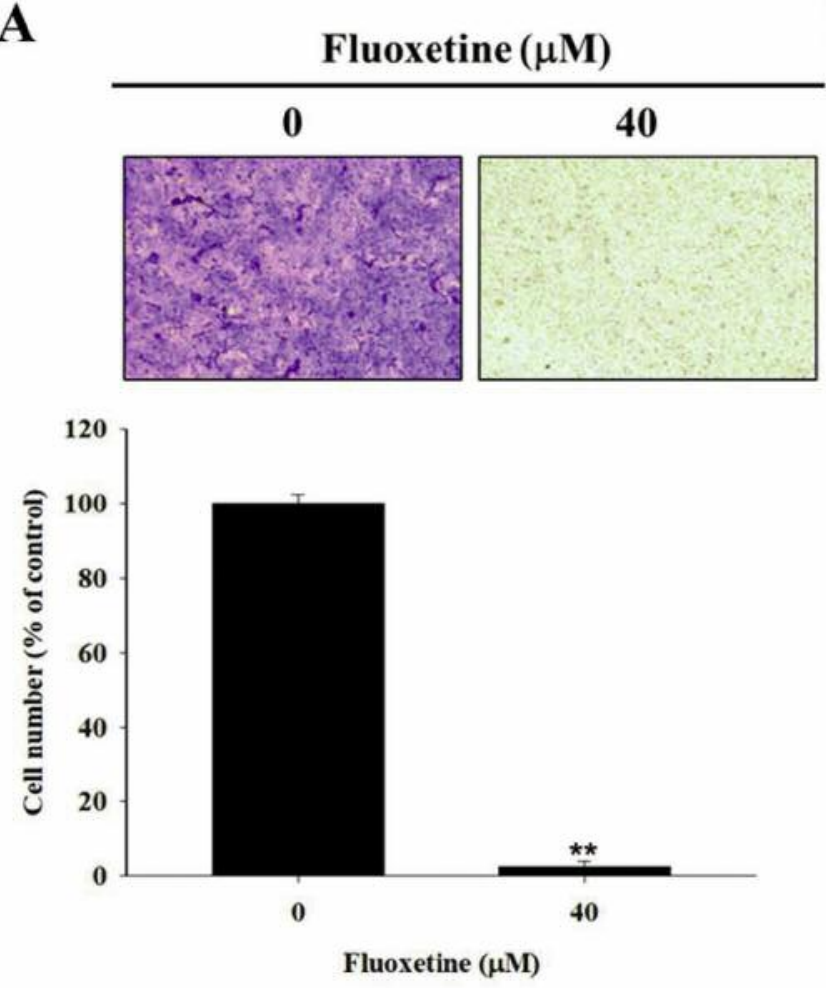

C
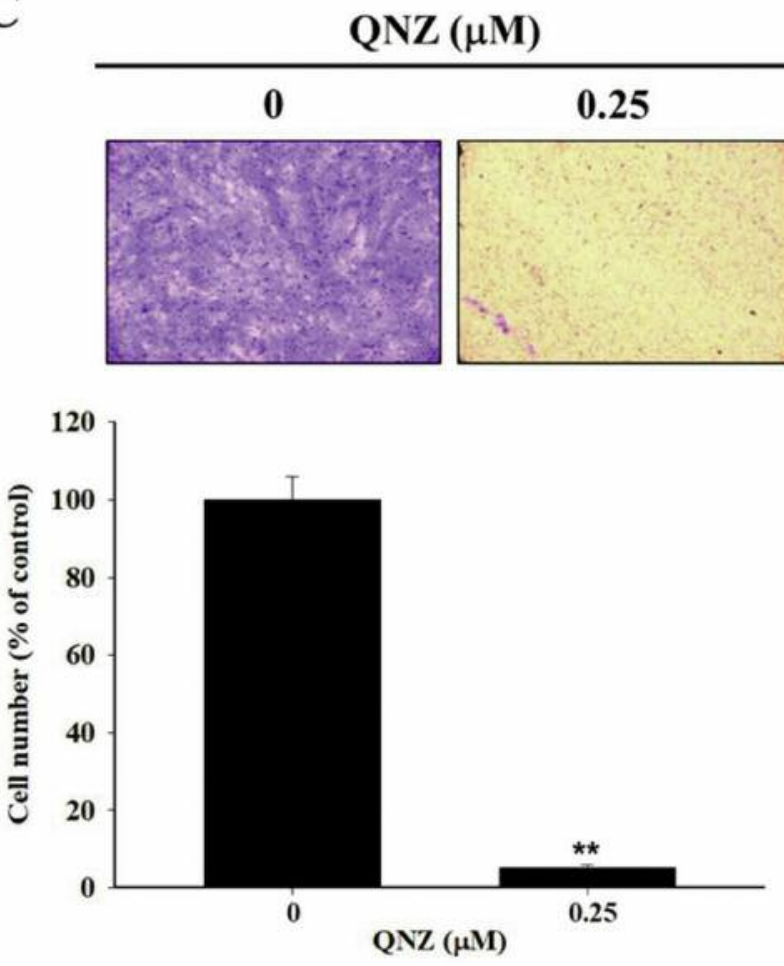

B Fluoxetine $(\mu \mathrm{M})$
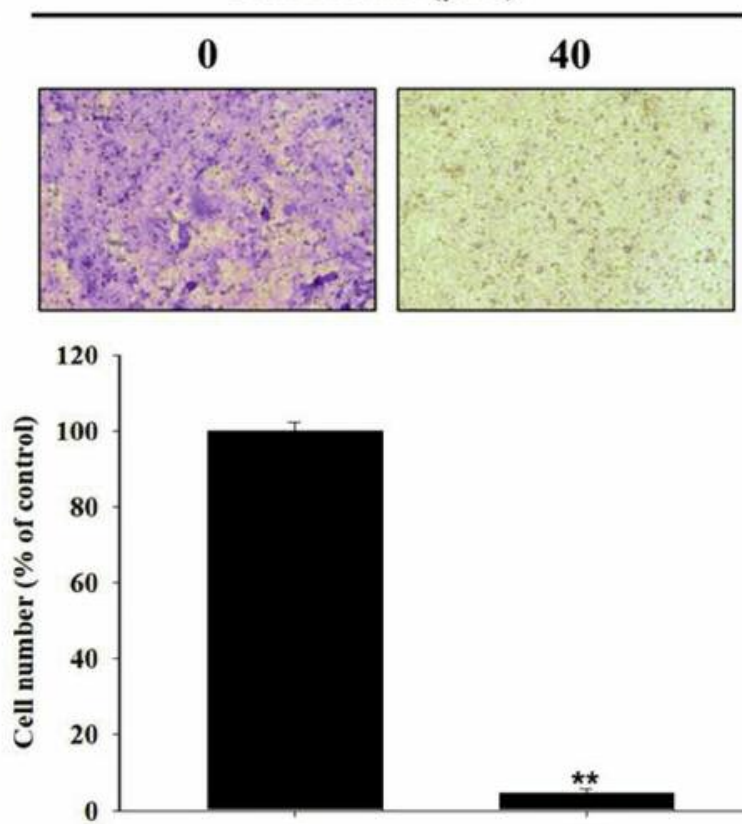

o

40

Fluoxetine $(\mu \mathrm{M})$

D

QNZ $(\mu \mathrm{M})$
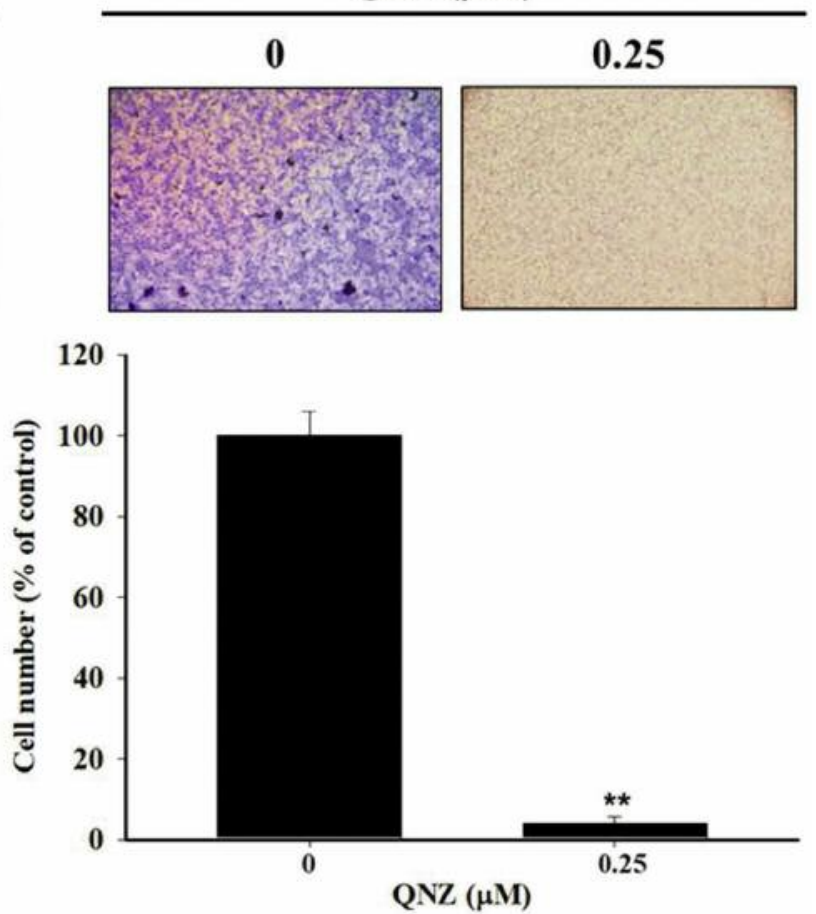

Figure 4. Effect of both fluoxetine and QNZ (NF-kB inhibitor) on cell migration and invasion of CL1-5-F4 cells. Cells were treated with $40 \mu M$ fluoxetine or $0.25 \mu \mathrm{M} Q N Z$ for $48 \mathrm{~h}$. After treatment, migration and invasion ability were assayed by cell migration and invasion assays. (A-B) fluoxetine treatment. (C-D) QNZ treatment. ${ }^{*} p<0.01$ as compared to $0 \mu M$ fluoxetine or $Q N Z$. 


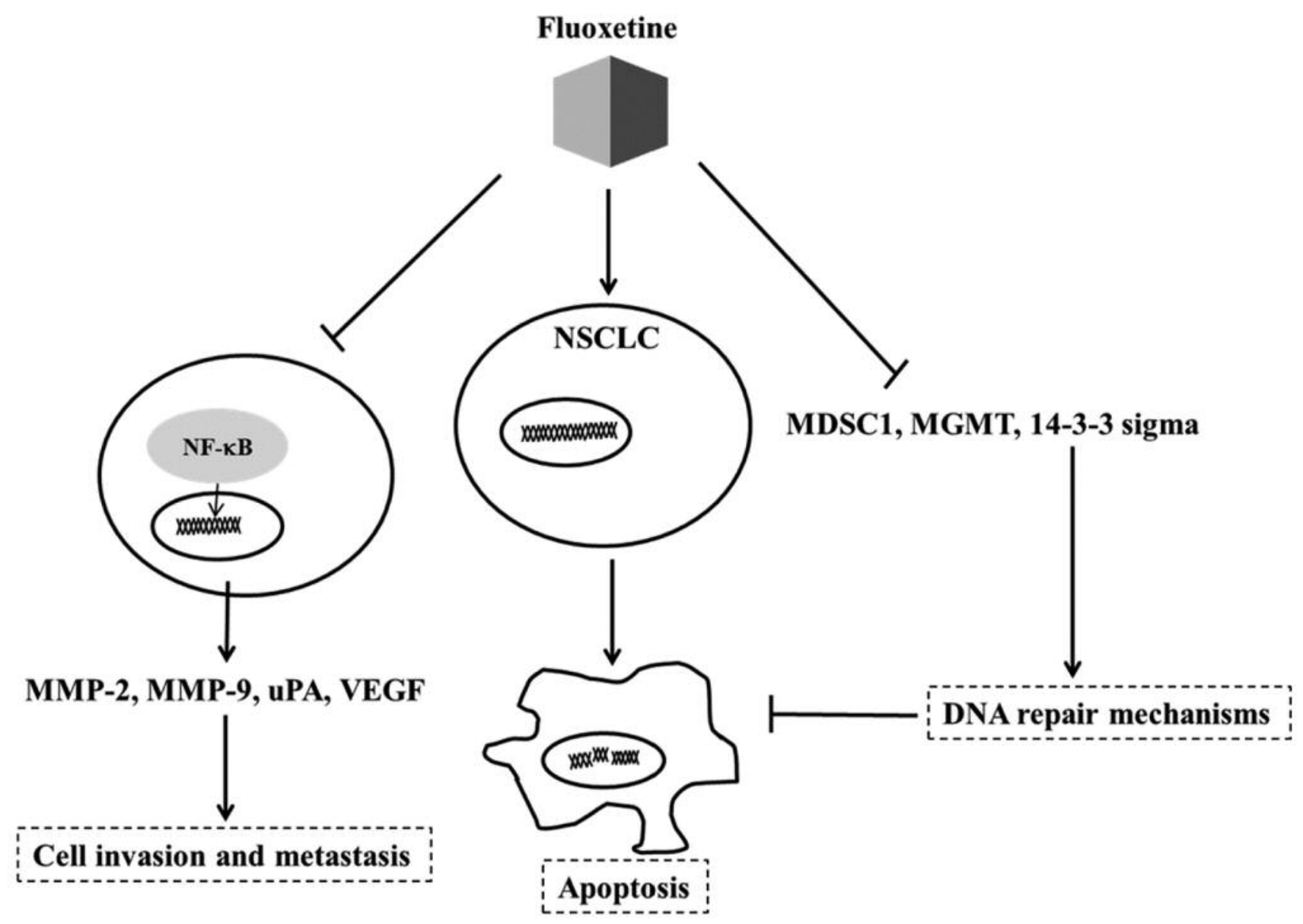

Figure 5. The potential anticancer properties of fluoxetine include induction of apoptosis, inhibition of DNA repair, and suppression of NF- $\mathrm{B} B$ modulated metastatic potential in NSCLC CL1-5-F4 cells.

Freire-Garabal et al. demonstrated that fluoxetine reversed development of lung metastasis by operative stress in rats. They hypothesized that fluoxetine reversed adverse effects of surgery through regulation of the immune response (30). Anti-cancer effects of antidepressants include initiation of antitumor immunity, promotion of apoptosis, and disruption of intracellular signal transduction resulting in inhibition of tumor growth (7). Mirtazapine, a noradrenergic and specific serotonergic antidepressant, has been demonstrated to inhibit tumor growth by up-regulating expression of anticancer cytokines interlukin-12 (IL-12) and interferon-gamma (INF $\gamma$ ) that trigger $\mathrm{CD}^{+}$and $\mathrm{CD}^{+}$T-cell infiltration within cancer tissue in colorectal cancer in vivo (31). Stepulak et al. showed that fluoxetine not only reduced phosphorylation of extracellular signal regulated kinase 1 and 2 (ERK1/2) and c-Myc but also up-regulated expression of p21(waf1) and p53 genes leading to suppression of tumor growth in NSCLC A549 cells (26).

Nuclear factor-kappaB (NF-kB), a transcription factor, modulates immunity, inflammation, and tumorigenesis by regulating the expression of $\mathrm{NF}-\mathrm{kB}$ target gene-encoding proteins (32). Positive NF-kB expression was found in patients with poorly or moderately differentiated NSCLC and correlated to unfavorable prognosis (33). Furthermore, active NF- $\mathrm{kB}$ signaling induces overexpression of metastasisassociated proteins such as MMP-2, MMP-9, uPA, and VEGF and acts as a target for lung cancer prevention and therapy (32). Inhibition of NF-kB activation may disrupt the metastatic mechanism of NSCLC. Zhao et al. also demonstrated that knockdown of NF-kB expression attenuated the metastatic potential in NSCLC in vitro (34). The results in that study demonstrated that both fluoxetine and QNZ (NF-kB inhibitor) reduced NF-kB activation, expression of metastasis-associated proteins (MMP-2, MMP9, uPA, and VEGF), and cell migration/invasion in CL1-5F4 cells (Figure $3 \mathrm{~A}$ and $\mathrm{B}$ ).

In conclusion, fluoxetine inhibited DNA repair and NFkB-modulated metastatic potential of NSCLC CL1-5-F4 cells (Figure 5). Fluoxetine may be used as a potential 
adjuvant treatment which can offer additional benefits to NSCLC patients.

\section{Conflicts of Interest}

The Authors declare that they have no competing interests regarding this study.

\section{Acknowledgements}

The present study was supported by a grant to J.-Y.W. (TTCRD105-01) and (CTU107-P-03) from the Taichung Tzu Chi Hospital, Buddhist Tzu Chi Medical Foundation (Taichung, Taiwan) and Central Tai-wan University of Science and Technology (Taichung, Taiwan), respectively. The Authors thank for their technical support the Translational Laboratory, Department of Medical Research, Taipei Medical Universi-ty Hospital, Taipei, Taiwan. This study was also supported by the Ministry of Science and Technology in Taiwan (grant number: MOST 107-2314-B-039068-MY2).

\section{References}

1 Araki T1, Yashima H, Shimizu K, Aomori T, Hashita T, Kaira $K$, Nakamura $T$ and Yamamoto K: Review of the treatment of non-small cell lung cancer with gefitinib. Clin Med Insights Oncol 6: 407-421, 2012.

2 Julian RM, Ping Yang, Stephen DC, Steven ES and Alex AA: Non-small cell lung cancer: epidemiology, risk factors, treatment, and survivorship. Mayo Clin Proc 83: 584-594, 2008

3 Ting CY, Wang HE, Yu CC, Liu HC, Liu YC and Chiang IT: Curcumin triggers DNA damage and inhibits expression of DNA repair proteins inhuman lung cancer cells. Anticancer Res 35 : 3867-3873, 2015.

4 Orlow I, Park BJ, Mujumdar U, Patel H, Siu-Lau P, Clas BA, Downey R, Flores R, Bains M, Rizk N, Dominguez G, Jani J, Berwick M, Begg CB, Kris MG and Rusch VW: DNA damage and repair capacity in lung cancer patients: prediction of multiple primary tumors. J Clin Oncol 26: 3560-3566, 2008.

5 Nichols L, Saunders R and Knollmann FD: Causes of death of patients with lung cancer. Arch Pathol Lab Med 136: 1552-1557, 2012.

6 Arrieta O, Villarreal-Garza C, Zamora J, Blake-Cerda M, de la Mata MD, Zavala DG, Muñiz-Hernández S and de la Garza J: Long-term survival in patients with non-small cell lung cancer and synchronous brain metastasis treated with whole-brain radiotherapy and thoracic chemoradiation. Radiat Oncol 6: 166172,2011

7 Frick LR and Rapanelli M: Antidepressants: influence on cancer and immunity. Life Sci 92: 525-532, 2013.

8 Zingone A, Brown D, Bowman ED, Vidal O, Sage J, Neal J and Ryan BM: Relationship between anti-depressant use and lung cancer survival. Cancer Treat Res Commun 10: 33-39, 2017.

9 Jahchan NS, Dudley JT, Mazur PK, Flores N, Yang D, Palmerton A, Zmoos AF, Vaka D, Tran KQ, Zhou M, Krasinska K, Riess JW, Neal JW, Khatri P, Park KS, Butte AJ and Sage J: A drug repositioning approach identifies tricyclic antidepressants as inhibitors of small cell lung cancer and other neuroendocrine tumors. Cancer Discov 3: 1364-1377, 2013.
10 Stopper H, Garcia SB, Waaga-Gasser AM and Kannen V: Antidepressant fluoxetine and its potential against colon tumors. World J Gastrointest Oncol 6: 11-21, 2014.

11 Caiaffo V, Oliveira BD, de Sá FB and Evêncio Neto J: Antiinflammatory, antiapoptotic, and antioxidant activity of fluoxetine. Pharmacol Res Perspect 4: e00231, 2016.

12 Koh SJ, Kim JM, Kim IK, Kim N, Jung HC, Song IS and Kim JS: Fluoxetine inhibits NF- $\mathrm{kB}$ signaling in intestinal epithelial cells and ameliorates experimental colitis and colitis-associated colon cancer in mice. Am J Physiol Gastrointest Liver Physiol 301: G9-19, 2011.

13 Hsu FT, Liu HS, Ali AAA, Tsai PH, Kao YC, Lu CF, Huang HS and Chen CY: Assessing the selective therapeutic efficacy of superparamagnetic erlotinib nanoparticles in lung cancer by using quantitative magnetic resonance imaging and a nuclear factor kappa-B reporter gene system. Nanomedicine 14: 10191031,2018

14 Liu YC, Wu RH and Wang WS: Regorafenib diminishes the expression and secretion of angiogenesis and metastasis associated proteins and inhibits cell invasion via NF-kB inactivation in SK-Hep1 cells. Oncol Lett 14: 461-467, 2017.

15 Wang WH, Chiang IT, Ding K, Chung JG, Lin WJ, Lin SS and Hwang JJ: Curcumin-induced apoptosis in human hepatocellular carcinoma j5 cells: critical role of ca(+2)-dependent pathway. Evid Based Complement Alternat Med 2012: 512907, 2012.

16 Chiang IT, Liu YC, Wang WH, Hsu FT, Chen HW, Lin WJ, Chang WY and Hwang JJ: Sorafenib inhibits TPA-induced MMP9 and VEGF expression via suppression of ERK/NF-kB pathway in hepatocellular carcinoma cells. In Vivo 26: 671-681, 2012.

17 Hsu FT, Liu YC, Chiang IT, Liu RS, Wang HE, Lin WJ and Hwang JJ: Sorafenib increases efficacy of vorinostat against human hepatocellular carcinoma through transduction inhibition of vorinostat-induced ERK/NF- $\mathrm{KB}$ signaling. Int $\mathrm{J}$ Oncol 45: $177-188,2014$

18 Ho CC, Lai KC, Hsu SC, Kuo CL, Ma CY, Lin ML, Yang JS and Chung JG: Benzyl isothiocyanate (BITC) inhibits migration and invasion of human gastric cancer AGS cells via suppressing ERK signal pathways. Hum Exp Toxicol 30: 296-306, 2011.

19 Pan PJ, Tsai JJ and Liu YC: Amentoflavone inhibits metastatic potential through suppression of ERK/NF- $\mathrm{kB}$ activation in osteosarcoma U2OS Cells. Anticancer Res 37: 4911-4918, 2017.

20 Chen Y, Li Z, Dong Z, Beebe J, Yang K, Fu L and Zhang JT: 14-3-3 $\sigma$ contributes to radioresistance by regulating DNA repair and cell cycle via PARP1and CHK2. Mol Cancer Res 15: 418428, 2017.

21 Cetintas VB, Tetik A, Cok G, Kucukaslan AS, Kosova B, Gunduz C, Veral A and Eroglu Z: Role of 14-3-3 $\sigma$ in resistance to cisplatin in non-small cell lung cancer cells. Cell Biol Int 37: 78-86, 2013.

22 Chen SH, Kuo CC, Li CF, Cheung CH, Tsou TC, Chiang HC, Yang YN, Chang SL, Lin LC, Pan HY, Chang KY and Chang JY: $\mathrm{O}(6)$-methylguanine DNA methyltransferase repairs platinumDNA adducts following cisplatintreatment and predicts prognoses of nasopharyngeal carcinoma. Int J Cancer 137: 1291-1305, 2015.

23 Brabender J, Usadel H, Metzger R, Schneider PM, Park J, Salonga D, Tsao-Wei DD, Groshen S, Lord RV, Takebe N, Schneider S, Hölscher AH, Danenberg KD and Danenberg PV: Quantita-tive $\mathrm{O}(6)$-methylguanine DNA methyltransferase methylation analysis in curativelyresected non-small cell lung cancer: associations with clinical outcome. Clin Cancer Res 9: 223-227, 2003 
24 Wang S, Zou Z, Luo X, Mi Y, Chang H and Xing D: LRH1 enhances cell resistance to chemotherapy by transcriptionally activating MDC1expression and attenuating DNA damage in human breast cancer. Oncogene 37: 3243-3259, 2018.

25 Wang Z, Zeng Q, Chen T, Liao K, Bu Y, Hong S and Hu G: Silencing NFBD1/MDC1 enhances the radiosensitivity of human nasopharyngeal cancer CNE1 cells and results in tumor growth inhibition. Cell Death Dis 6: e1849, 2015.

26 Stepulak A, Rzeski W, Sifringer M, Brocke K, Gratopp A, Kupisz K, Turski L and Ikonomidou C: Fluoxetine inhibits the extracellular signal regulated kinase pathway and suppresses growth of cancer cells. Cancer Biol Ther 7: 1685-1693, 2008

27 Shapovalov Y, Zettel M, Spielman SC, Amico-Ruvio SA, Kelly EA, Sipe GO, Dickerson IM, Majewska AK and Brown EB: Fluoxetine modulates breast cancer metastasis to the brain in a murine model. BMC Cancer 14: 598, 2014.

28 Zabel A and Debus J: Treatment of brain metastases from nonsmall-cell lung cancer (NSCLC): radiotherapy. Lung Cancer 45: S247-S252, 2004.

29 Chen JJ, Peck K, Hong TM, Yang SC, Sher YP, Shih JY, Wu R, Cheng JL, Roffler SR, Wu CW and Yang PC: Global analysis of gene expression in invasion by a lung cancer model. Cancer Res 61: 5223-5230, 2001

30 Freire-Garabal M, Núñez MJ, Pereiro D, Riveiro P, Losada C, Fernández-Rial JC, García-Iglesias E, Prizmic J, Mayán JM and Rey-Méndez M: Effects of fluoxetine on the development of lung metastases induced by operative stress in rats. Life Sci 63: 31-38, 1998.
31 Fang CK, Chen HW, Chiang IT, Chen CC, Liao JF, Su TP, Tung CY, Uchitomi Y and Hwang JJ: Mirtazapine inhibits tumor growth via immune response and serotonergic system. PLoS One 7: e38886, 2012.

32 Chen WS, Li Z, Bai L and Lin Y: NF-kappaB, a mediator for lung carcinogenesis and a target for lung cancer prevention and therapy. Front Biosci 16: 1172-1185, 2011.

33 Zhang Z, Ma J, Li N, Sun N and Wang C: Expression of nuclear factor-kappaB and its clinical signif-icance in nonsmall-cell lung cancer. Ann Thorac Surg 82: 243-248, 2006.

34 Zhao M, Gao Y, Wang L, Liu S, Han B, Ma L, Ling Y, Mao S and Wang $\mathrm{X}$ : Overexpression of integ-rin-linked kinase promotes lung cancer cell migration and invasion via NF-kB-mediated upregulation of matrix metalloproteinase-9. Int J Med Sci 10: 995-1002, 2013.

Received August 1, 2018

Revised August 15, 2018

Accepted August 16, 2018 